\title{
RESTRICTIONS ON POLITICAL CAMPAIGNS IN JAPAN
}

\author{
MASAhIRo UsakI*
}

I

Introduction: The Constitution of JaPAN AND Political Freedom

The Constitution of Japan proclaims in its preamble that "sovereign power resides with the people," demanding that governmental affairs be executed in accordance with the people's will. Article 15 of the Constitution provides that " $\mathrm{t}$ ] he people have the inalienable right to choose their public officials and to dismiss them," and Article 16 states that "[e]very person shall have the right of peaceful petition." Needless to say, for governmental affairs to be done in accordance with the people's will, the people need to be informed enough to be able to form their own opinions and to be given opportunities to express and exchange those opinions. Therefore, in Article 21, the Constitution guarantees "[f]reedom of assembly and association as well as speech, press and all other forms of expression," including political freedom.

The constitutional guarantee of political freedom means that the people have the right to participate in the governmental process and the right to engage freely, whether directly or indirectly, in political campaigns and activities. The constitutional guarantee of political freedom not only provides to the people the right to participate in the political process in a narrow sense, such as by becoming a member of the Diet or a local assembly, engaging in election campaigns, organizing or affiliating with political groups, and making petitions, but it also provides for broader freedoms, such as expressing political views through speech, the press, assembly, demonstration, and all other forms. In this respect, political freedom has a social character that functions outwardly. Political freedom does not reside in one's mind, and it often has outward manifestations that conflict with other individuals' rights and social interests. Thus, political freedom is not unlimited. If there is any conflicting compelling interest, we have to accept certain restrictions upon political freedom. Nevertheless, political freedom is essential to a democratic government. Therefore, any restriction upon that freedom requires deliberate consideration of whether the restriction is constitutional.

Copyright () 1990 by Law and Contemporary Problems

* Professor, Faculty of Law, Tsuru University; Visiting Scholar, Duke University School of Law. For comprehensive studies by American scholars on the issues discussed below, see L. BEER, Freedom of EXPRESSion In JAPAN (1984). I owe a great deal to Professor Beer's book in preparing this article. 
In that regard, Article 13 of the Constitution states that constitutional rights shall "be the supreme consideration in legislation and in other governmental affairs." Thus, the rights guaranteed by the Constitution cannot be easily restricted, even by statute. Political freedom justifies the exercise of governmental power in a democratic state, so it is deemed to be the most fundamental right. In other words, this freedom is a crucial right that underlies democracy and therefore occupies the preferred position among other constitutional rights and freedoms. In this respect, it is different from any other right. Thus, when political freedom is to be restricted for some reason, the restrictive measure is subject to strict scrutiny of its constitutionality.

The purpose of this Article is to examine the current restrictions on political campaigns and activities in Japan from the basic point of view just described. Despite constitutional protection, the present condition of political freedom in Japan contains many problems and needs improvement.

II

\section{Restrictions on Political Campaigns in Japan}

A. Restrictions on Political Activities by Public Employees

1. The Structure of Existing Laws. Public employees are those people who perform the public services of national or local public entities. In terms of freedom of political activities, public employees are subject to extensive restrictions under the National Public Employees Law ("NPEL") ${ }^{l}$ and the Local Public Employees Law ("LPEL"). ${ }^{2}$

Article 102, paragraph 1, of the NPEL provides that:

Personnel shall neither solicit nor receive donations or other benefits for a political party or for a political purpose, nor shall they in any manner have a part in such acts; and apart from exercising their right to vote, they must not engage in political acts, as prescribed by the Rules of the National Personnel Authority.

Article 110 , paragraph 1 , number 19 , provides that any person who violates the restrictions placed on political acts shall be sentenced to penal servitude not exceeding three years or fined an amount not exceeding one hundred thousand yen. Rule 14-7 of the National Personnel Authority ("NPA") prohibits seventeen "political acts" done for "political purposes," such as giving support to or making objections against a specific candidate for public office, a specific political party, a specific cabinet, or a specific policy of the government. $^{3}$

Rule 14-7 lists a wide range of "political acts." 4 It includes not only abuse of authority or position, bribery, and the establishment of a political party or group, but it also lists publishing, editing, or circulating newspapers and magazines of a political party or group, or assisting therein; planning, leading,

1. National Public Employees Law, Law No. 120, 1947.

2. Local Public Employees Law, Law No. 261, 1950.

3. NPA Rule 14-7, 1949.

4. Id. $\uparrow 6$. 
or participating in signature campaigns; planning, organizing, or leading a parade or a demonstration, or assisting therein; expressing political opinions publicly by loudspeaker, radio, or any other means; publishing, circulating, or distributing literature and drawings, or posting them on a public bulletin board or on other public facilities; and making or distributing flags, stickers, or badges that show a certain political contention, or displaying, putting up, or wearing them during office hours.

These regulations are applicable to all public employees, even during offduty hours. Consequently, public employees are banned under Rule 14-7 from almost all political activity except for exercising their right to vote. Local public employees are subject to similar regulations under the LPEL. However, the scope of political acts prohibited under the LPEL is narrower than under the NPEL and NPA Rule 14-7. In addition, the LPEL provides no criminal punishment for violation of its provisions; only administrative sanctions are imposed. 5 In any case, public employees are placed under extensive restrictions on their political activities-restrictions to which an ordinary citizen is never subject because of the constitutional guarantee.

The current regulative measures were first introduced in 1947 in accordance with the strong suggestions by the General Headquarters of the Allied Powers ("GHQ"), without sufficient deliberation by the Diet. At the time, the GHQ was anxious about the increase in antigovernment political activities by public employees. Furthermore, it is obvious that the codification of these measures into public employee laws after 1952 was based on the Hatch Act of 1940 and the Rules of the United States Federal Personnel Commission. However, there are apparent differences between the NPEL and NPA Rule 14-7 and their equivalents in the United States. In the United States, only the abuse of authority and position is prohibited, and government employees are not restrained from expressing their own opinions as to any political affairs or candidates. Needless to say, there is no regulation on displaying or wearing political drawings, stickers, or badges in the United States. On the other hand, in Japan there are many restrictions, accompanied by criminal punishment.

2. Justification for Restrictions on Political Activities by Public Employees. Article 15, paragraph 2, of the Constitution rationalizes the wide range of restrictions on political activities by public employees. It provides that all public officials and employees are "servants of the whole community." Thus, early court decisions and legal theories tended to regard the restrictions as not infringing on the constitutional guarantee of freedom of political activities for public employees because these restrictions were necessary for "the public welfare" and "the public interest." 6

5. LPEL, art. 36 .

6. See, e.g. , 1 Hōgaku KyōKai, Chūkai Nihonkoku Kenpō 365-67 (1953). See also 12 Keishū 942 (Sup. Ct., G.B., Apr. 16, 1958); 12 Keishū 501 (Sup. Ct., G.B., Mar. 12, 1958). 
However, the concept of "servants of the whole community" is too inclusive and abstract to justify the restrictions on freedom of political activities. Because they relate to a preferred freedom, the restrictions should be kept to a strict minimum, and determining the minimum necessary restriction requires a close, ad hoc analysis of the circumstances surrounding each case. This approach is incompatible with one that treats all public officials and employees equally. Thus, today, the concept of "servants of the whole community" should be considered as an ideal for the execution of duties by public officials and employees whose positions are based on the people's will, not as a reason to justify the restrictions on public employees' political rights. ${ }^{7}$

In the Sarufutsu case, ${ }^{8}$ these restrictions faced a serious constitutional challenge for the first time. In this case, a postal worker in the village of Sarufutsu, Hokkaido, was indicted for violating Article 102 of the NPEL and Rule 14-7 of the NPA. In the 1967 election to the House of Representatives, the postal worker put several election campaign posters for a Socialist candidate up on a bulletin board during off-duty hours and distributed the same posters to some friends, asking them to display the posters in public. In 1968, the Asahikawa District Court acquitted the defendant, holding that the provisions of the NPEL as applied to the defendant's activities violated the right to free expression protected by Article 21 of the Constitution and the right to due process of law as provided by Article 31. The court concluded that the restrictions in question exceeded the constitutionally permissible limit by imposing criminal punishment for legitimate union activities, since the degree of restrictions on freedom of political activities, even by public employees, should be the minimum necessary due to its importance in a democratic society. The court stated, "If there are any narrower sanctions than those provided in the law, and it is possible to attain the same legislative purpose equally by them, the broad sanction provided in the law is considered to be unconstitutional as an excessive measure beyond the minimum necessity."9 This decision is regarded as an application of the less restrictive alternative test. ${ }^{10}$ The Sapporo High Court affirmed the district court in 1969 on the same reasoning. "

Around the same time, the Tokushima District Court and the Aomori District Court, in similar cases, held that the restrictions provided by the NPEL and NPA Rule 14-7 violated Articles 21 and 31 of the Constitution. ${ }^{12}$ The Takamatsu High Court affirmed the former district court decision,

7. See, e.g., K. Sato, Kenpō 302 (1981); Ashibe, Komuin to Jinken, in 1 ShinPan KenPō Enshu 173 (S. Kiyomiya, I. Sato, T. Abe \& Y. Sugihara eds. 1980).

8. Japan v. Osawa (The Sarufutsu Case), 28 Keishū 393 (Sup. Ct., G.B., Nov. 6, 1974) (rev'g 514 Hanrei Jihō 20 (Asahikawa Dist. Ct., Mar. 25, 1968) and 560 Hanrei Jihō 30 (Sapporo H. Ct., June 24, 1969)).

9. 514 Hanrei Jihō at 24.

10. N. Ashibe, Gendai Jinkenron 267-68, 273 (1974).

11. 560 Hanrei Jihō at 31 .

12. 611 Hanrei Jihō 99 (Aomori Dist. Ct., Mar. 30, 1970); 560 Hanrei Jihō 33 (Tokushima Dist. Ct., Mar. 27, 1969). 
emphasizing a public employee's right to political expression as a citizen. ${ }^{13}$ In 1971, the Tokyo District Court decided the Zentei placard case in favor of the plaintiff. ${ }^{14}$ In this case, a postal employee had participated in a May Day demonstration carrying a banner that read: "Overthrow the Sato Administration which supports the Vietnam War." The May Day was a Sunday, and the employee was off duty. He successfully contended that the administrative disciplinary action against him was invalid because it violated his right of free expression guaranteed by the Constitution. The court stated that a restriction on political freedom should be the minimum necessary to maintain administrative neutrality and "the standard of constitutionality is that there is no less restrictive alternative." 15 The Tokyo High Court affirmed the decision in 1973. ${ }^{16}$ In the Statistics Bureau of the Prime Minister's Office case, four women employees were found guilty and fined ten thousand yen each for handing out copies of a leaflet listing names of candidates for the 1965 election to the Tokyo Metropolitan Assembly. ${ }^{17}$ The Tokyo High Court reversed the convictions, however, stating that the employees' activities were normal union activities without substantial illegality. ${ }^{18}$

In 1974, the Sarufutsu case came before the Supreme Court. The Court reversed the Asahikawa District Court's finding of unconstitutionality, upholding the broad, extensive, and uniform restrictions on the freedom of political activities of public employees under the NPEL and NPA Rule 14-7. The Court emphasized that public employees were "servants of the whole community," 19 and found the common interest in maintaining the political neutrality of these servants sufficient to support the broad restrictions:

In order to maintain administrative neutrality and public trust in administration, imposing a prohibition upon public employees' political activities which are likely to impede political neutrality is a measure to protect common interests of the whole people, and its purpose is justifiable .... [E]ven if the prohibition does not consider the distinctions in a public employee's position and authority, between working hours and off-duty hours, and in using public facilities or not, and if it is not limited to the extent that the activities impede the neutral execution of administration directly and concretely, it does not lose the reasonable relation between the prohibition and its purpose. ${ }^{20}$

The Court went on to state that the restrictions on political activities by public employees were not aimed at the expression of opinion itself; rather, they were aimed at preventing the harm that the activities were expected to cause. ${ }^{21}$ According to the Court, the restrictions were "indirect and subordinate," 22 and, therefore, the test used in the judicial review of this case

13. 646 Hanrei Jihō 95 (Takamatsu H. Ct., May 10, 1971).

14. 22 Gyōshū 1755 (Tokyo Dist. Ct., Nov. 1, 1971).

15. 22 Gyōshū at 1772 .

16. 24 Gyōshū 1018 (Tokyo H. Ct., Sept. 19, 1973).

17. 566 Hanrei Jihō 3 (Tokyo Dist. Ct., June 14, 1969).

18. 665 Hanrei Jihō 29 (Tokyo H. C., Apr. 5, 1972).

19. 28 Keishū 393.

20. Id. at 400-01.

21. Id. at 401 .

22. Id. 
could be looser than that usually applied to restraints upon freedom of expression or political freedom.

Four justices filed a dissenting opinion, stating that the provisions of the NPEL and NPA Rule 14-7 were invalid because they violated, among others, Articles 21, 31, and 41 of the Constitution. The dissenters would have upheld the lower court decision and said that "as to the prohibition with criminal punishment, the restrictions on the freedom of political expression by public employees [under Rule 14-7, paragraph 6] are excessively broad and unconstitutional."'23

On the same day, the Supreme Court overturned the Takamatsu High Court decision in the Tokushima Post Office case. ${ }^{24}$ Later, in 1980, the Court also overturned the Tokyo High Court decision in the Zentei placard case, upholding the administrative disciplinary action for political activities. ${ }^{25}$

3. An Appraisal of Restrictions on Political Activities by Public Employees. Despite the Supreme Court decisions, many scholars have questioned the constitutionality of the restrictions under the NPEL and NPA Rule 14-7 for several reasons. First, the restrictions are excessively broad in violation of Article 21 of the Constitution, since the outright restrictions on political activities of all public officials and employees reach activities protected by the Constitution. ${ }^{26}$ Second, the sanction for the violation exceeds the limit that is the minimum necessary to attain the legislative purpose. ${ }^{27}$ In this respect, the restrictions are suspected to be unconstitutional under Article 31, which provides that any criminal penalty shall not be imposed "except according to procedure established by [due process of] law." Third, NPA Rule 14-7 goes beyond the constitutionally permissible limits established by Articles 31, 41, and 73. Article 41 provides that the Diet shall be "the sole lawmaking organ of the state," and Article 73 provides that cabinet orders cannot include penal provisions unless authorized by law. Article 102 of the NPEL, however, delegates the determination of the extent of criminal punishment to the NPA, an agency of the executive branch of government. This delegation of power, it is argued, violates the provisions of the Constitution listed above, which require that the discipline of public officials and employees be based on a statutory standard. ${ }^{28}$

The Constitution presupposes the existence of public officials and employees, so it admits a special legal relationship between them and the national and local governments. Maintenance of an efficient public service system is a legitimate public interest, and, in order to fulfill that interest, it is constitutionally acceptable to impose minimal restrictions upon the rights and

23. Id. at 420 .

24. 28 Keishū 694 (Sup. Ct., G.B., Nov. 6, 1974).

25. 34 Minshū 959 (Sup. Ct., G.B., Dec. 23, 1980).

26. N. Ashibe, Kenpōsoshō no Gendaiteki Tenkai 197, 237 (1981). See also dissenting opinion by four justices in the Sarufutsu case, 28 Keishū at 419-20.

27. M. ITO, KENPō 208 (1982).

28. R. Arikura, Kenpō ni Okeru Hanrei no Igı 364-68 (1979). 
freedoms of public officials and employees. However, the restrictions are exceptions to the general rights and freedoms of Japanese citizens and apply only to public employees and officials. Whether there is any compelling reason to justify such restrictions, and whether they are within the limit of minimum necessity, must be closely examined. Especially when rights that are crucial to democracy such as political freedom are involved, close and accurate analysis is required.

From the point of view just described, it seems in the Sarufutsu case that the approach of the lower courts and the dissenting justices is far more appropriate than that of the Supreme Court's majority opinion. There is serious doubt about the Court's approach in upholding outright restraints on all public employees without considering relevant factors such as the employee's position and authority and whether the alleged activities were done during off-duty hours. In conclusion, it is my opinion that there is doubt about the constitutionality of the existing restrictions under Article 102 of the NPEL and NPA Rule 14-7, because restrictions prevent public employees from exercising their political rights, even during off-duty hours, and forbid them to engage in almost all activities relating to politics and government.

\section{B. Restrictions on Election Campaigns under the Public Officials Election Act}

1. Structure of Regulation under the Public Officials Election Act. The preamble to the Constitution states: "We, the Japanese people, acting through our duly elected representatives in the National Diet . . .." Article 15 provides that the right to choose and dismiss public officials is an "inalienable right" of the people. Thus, it is quite obvious that the election, as a procedure to choose representatives or public officials, has an extremely important position under the Constitution. Success in democracy depends upon whether the electoral process is based upon the freely expressed will of the people. Consequently, the freedom of political campaigns must be adequately protected during the electoral process. However, the current Public Officials Election Act ("POEL") ${ }^{29}$ imposes extensive restrictions on election campaigns, and there are serious questions about whether these restrictions are compatible with the principles of democracy.

Restrictions on election campaigns under the POEL consist of the following:

1. Election campaigns by candidates are permitted only during the election period. Election campaigns before the notice of candidacy are prohibited as "pre-election campaigning." 30

2. Door-to-door canvassing for votes is forbidden. "No one shall conduct a door-to-door canvass with the intention of soliciting a

29. Public Officials Election Act, Law No. 100, 1950.

30. Id. art. 129. 
vote for oneself or another person or to prevent the voter from voting for another person." 31

3. Signature campaigns are prohibited. "No one shall conduct a signature campaign with the intention of soliciting a vote for oneself or another person, or to prevent the voter from voting for another person." 32

4. Repeated calling activities are banned. "No one shall conduct repeated calling activities for an election campaign."'33

5. Each candidate may have only one campaign office, one campaign car, and one campaign loudspeaker. ${ }^{34}$

6. Written campaign materials are prohibited except as expressly allowed by law. The number and size of campaign posters and handbills are strictly limited by the law, as is the number of campaign postcards. Also, putting up posters is limited to official poster boards within election districts where posters of all candidates are displayed. ${ }^{35}$

7. Reports and comments by newspapers and magazines are banned unless the following requirements are met: (a) newspapers must be published more than three times a month, and magazines must be published more than once a month, with running numbers and with charge; ${ }^{36}$ (b) the newspaper or magazine must have a third class mail license; (c) the newspaper or magazine must have been continually published for one year (six months for daily newspapers) in advance of the election, during which time it must have met the requirements contained in (a) and (b). ${ }^{37}$

8. Candidates may not use the mass media except as allowed by law. They can, however, use newspaper advertisements and television and radio time in predetermined amounts. The government funds such advertisements. ${ }^{38}$

9. Candidates may hold private speech meetings at public facilities without charge. However, the time available for such meetings is limited; a candidate may hold only one meeting in a given facility and notice to the Election Administration Commission is required in advance. Any other speech meetings are not allowed. ${ }^{39}$

31. Id. art. 138, I 1 .

32. Id. art. 138(2).

33. Id. art, $140(2)$.

34. Id. arts. 131,141 .

35. Id. arts. $142,143,144,144(2)$.

36. The words "with running number and with charge" mean that the issues must be numbered and that a price must be charged for each issue.

37. Id. art. 148.

38. Id. arts. 149-51.

39. Id. arts. 161-64. 
10. Sidewalk speeches for election campaigns may not be made between the hours of 8 p.m. and 8 a.m. the next morning. ${ }^{40}$

11. Various kinds of political activities by political parties and other groups in the election are also strictly limited. These activities include holding political speech meetings and sidewalk speeches, putting up political posters and notice boards, distributing handbills, using cars and loudspeakers for political propaganda, and circulating or distributing free publications such as special or extra issues. ${ }^{41}$

These extensive restrictions on election campaigns are extraordinary among modern democratic states. The restrictions in Japan originated with the enactment of the Universal Suffrage Law in 1925. The law established universal male suffrage without property requirements for the first time in Japan, but at the same time introduced a variety of restrictions on election campaigns. These restrictions included prohibition of door-to-door canvassing and extensive regulations on campaign speeches and written materials. It was explained that the restrictions were necessary to maintain the decency of candidates and to prevent injustices such as bribery. ${ }^{42}$ In fact, these restrictions were aimed at preventing the political influence of the unpropertied public, who did not have enough money to carry on election campaigns. ${ }^{43}$

After World War II, when the current democratic Constitution was adopted and the election laws were revised, an overall reexamination of campaign restrictions was supposedly required. In those days, however, most people, especially Diet members, did not understand the meaning of free election campaigns, since they were not familiar with democratic government. ${ }^{44}$ The POEL, enacted in 1950, partially lifted the ban on doorto-door canvassing, but a 1952 amendment revived most prewar restrictions. The POEL's basic structure has remained intact to this date. Since the mid1970s, various additional regulations on speech and written materials have been introduced. The rationale of these regulations, however, is doubtful because they seem to be part of a partisan strategy of the ruling party to hinder the election of reformist local governments supported by opposition parties.

2. Restrictions on Election Campaigns and the Judiciary. The restrictions on election campaigns, especially on door-to-door canvassing and on speech and

40. Id. art. 164(6).

41. Id. art. 201.

42. Naimushō, Shūgingin Senkyohō Kaisei Riyūsho 206 (1925), cited in Okudaira, Genton no Jiyu to Shihoshinsa, 4 University of Tokyo Institute of Social Science, Kinonteki Jinken 284 (1968).

43. See 2 Y. Okudaira, Dōjidai Eno Hatsugen 287-88 (1979) (testimony before the Isumo Br., Matsue Dist. Court, Sept. 21 , 1977, see infra note 55); Okudaira, Kobetsuhomon to Genron no Jiyü, Asahi Shinbun, evening ed., Aug. 2, 1968.

44. See Soma, Senkyoseido no Kaikaku, in 3 University of Tokyo Institute of Social Science, Sengo Kaikaku 115 (1974). 
written materials, are excessively regulatory and irrational. Many scholars and lower court decisions have considered them to be unconstitutional.45 Many cases challenging such restrictions have come before the Supreme Court; however, since 1950, the Court has consistently held them to be constitutional. In that year, the Court upheld the ban on door-to-door canvassing for the first time, saying that it was not unconstitutional even if "the measure of insuring fair elections by banning door-to-door canvassing may result in a certain degree of restriction of freedom of speech [because canvassing] is accompanied by a variety of harm." 46 The Court did not consider what kind of harm canvassing would cause. ${ }^{47}$

In 1968, the second Petty Bench of the Court pointed out the harm canvassing creates. ${ }^{48}$ First, door-to-door canvassing raises the possibility of injustice, such as bribery or threats. Second, it creates the opportunity for other harassment or unfair influence on the voter. Third, door-to-door canvassing causes excessive competition among candidates. These reasons have been the ones most commonly given by the Court in decisions on the ban on canvassing. However, the facts in most cases that came to the courts made it clear that, while the accused persons had solicited votes, they had not committed any of these injustices. As a result, there was no perceptible harm and it was the mere "possibility" of harm that was asserted in door-to-door canvassing cases. Nevertheless, the reasons have been repeated by the Court without serious reexamination. 49

On June 15, 1981, the Court again upheld the prohibition on canvassing. ${ }^{50}$ The Court reasoned that the prohibition of door-to-door visits was not intended to restrict the expression of ideas and opinions, but to prevent the harm brought by improper means and methods of expression. In addition, the Court reasoned that the ban on canvassing was an indirect or a subordinate restriction on expression resulting from a prohibition of means and methods, and that the benefits from insuring free and fair elections gained by the prohibition far outweighed the loss from restricting freedom of expression. Finally, the Court decided that the determination of whether door-to-door canvassing should be banned entirely was a matter of legislative policy. Therefore, Article 138 of the POEL was not beyond the reasonable and necessary limit and did not violate Article 21 of the Constitution.

Despite these decisions by the Court, the causal nexus between door-todoor canvassing and the asserted harm has yet to be established adequately. Not only have scholars severely criticized the ban on canvassing, but several

45. Okudaira, supra note 42, at 267. See infra text accompanying notes 53-56. For other cases that overturned the ban on door-to-door canvassing, see 944 Hanrei Jihō 133 (Fukuoka Dist. Ct., Yanagawa Br., Sept. 7, 1979); 962 Hanrei Jihō 130 (Morioka Dist. Ct., Tono Br., Mar. 25, 1975).

46. 4 Keishū 1799, 1802 (Sup. Ct., G.B., Sept. 27, 1950).

47. Okudaira, supra note 42, at 264-65.

48. 22 Keishū 1319 (Sup. Ct., 2d P.B., Nov. 1, 1968).

49. For other Supreme Court decisions upholding the ban on canvassing, see 964 Hanrei Jihō 129 (Sup. Ct., G.B., June 6, 1980); 933 Hanrei Jihō 147 (Sup. Ct., G.B., July 5, 1979); 23 Keishū 235 (Sup. Ct., G.B., Apr. 23, 1969); 21 Keishū 1245 (Sup. Ct., G.B., Nov. 21, 1967).

50. 35 Keishū 205 (Sup. Ct., G.B., June 15, 1981). 
Supreme Court Justices have also offered opinions that are critical of the ban. In his supplementary opinion to the third Petty Bench decision on July 21 , 1981, Justice Masami Ito stated that the reasons supporting the constitutionality of the ban on door-to-door canvassing were "not persuasive enough." 51 Although the lower court decisions have been divided on the issue, ${ }^{52}$ not a few of them have found the ban to be invalid as a violation of Article 21 of the Constitution. For example, in 1968, the Myoji Summary Court in Wakayama stated that "it is not permissible to prohibit door-to-door canvassing entirely because the restriction lacks the 'clearness' requirement of danger."'53 In 1969, the Saku branch of the Nagano District Court pointed out that door-to-door canvassing provided an opportunity for a candidate to criticize an opponent in a direct conversation between the candidate and a voter and thus "has a great advantage not to be substituted by other election campaign techniques which are likely to end in one-way communication."54 Furthermore, in 1979, the Isumo branch of the Matsue District Court stated that "the ban on door-to-door canvassing exceed[ed] the limit of reasonable and necessary minimum." 55 These decisions examined the asserted harm in detail and concluded that there existed no direct causal nexus between doorto-door canvassing and the asserted harm. The 1980 decision by the Matsue branch of the Hiroshima High Court ${ }^{56}$ was the first on the high court level to invalidate the ban on door-to-door canvassing, but it was overturned by the Supreme Court in June 1981.57 In the decision, the high court, like other lower courts, examined the allegations that door-to-door canvassing was harmful to candidates' decency, extremely troublesome for candidates, disadvantageous to incumbents, and led to emotional influences on the elections. The high court found that the reasons offered for prohibiting canvassing do not justify the suppression of freedom of expression. The possibility of injustice, such as bribery, is very abstract, and voter harassment can be eliminated easily by other means. ${ }^{58}$ The high court concluded that the total ban on door-to-door canvassing was not a reasonable and necessary restriction permissible under the Constitution. ${ }^{59}$ To say the least, these rulings by the lower courts rest upon far more persuasive reasoning than those of the Supreme Court.

As for regulations on the use of written election materials, the Supreme Court also has consistently found these regulations to be constitutional, stating that they were reasonable and necessary to maintain "the public

51. 35 Keishū 568, 577 (Sup. Ct., 3d P.B., July 21, 1982) (Ito, J., supp. op.).

52. For examples upheld by the lower courts, see 915 Hanrei Jihō 124 (Tokyo H. Ct., May 30, 1978); 21 Kokeishū 582 (Tokyo H. Ct., Nov. 27, 1968); 538 Hanrei Jihō 87 (Osaka H. Ct., Sept. 25, 1968); 505 Hanrei Jihō 77 (Sapporo Dist. Ct., Iwamisawa Br., Oct. 24, 1967).

53. 512 Hanrei Jihò 76, 77 (Myoji Summ. Ct., Mar. 12, 1968).

54. 234 Hanrei Jihō 32, 33 (Nagano Dist. Ct., Saku Br., Apr. 18, 1969).

55. 923 Hanrei Jihō 141, 146 (Matsue Dist. Ct., Isumo Br., Jan. 24, 1979).

56. 964 Hanrei Jihō 134 (Hiroshima H. Ct., Matsue Br., Apr. 24, 1980).

57. 35 Keishū 205.

58. 964 Hanrei Jihō at 136-38

59. Id. at 138 . 
welfare" by preserving the freedom and fairness of elections. ${ }^{60}$ However, written materials are not only a means of communicating ideas and opinions; they are an essential means of communication in election campaigns and political activities. Thus, to impose substantial restrictions on written materials during the election process is to neglect political freedom. Especially during the election process, political freedom should be strongly protected.

What kinds of harms would be caused by leaving written political materials unfettered in the election period? As an example, there was a case in which a publisher of a small-town newspaper was indicted for violating Article 148 of the POEL. He printed comments about the ongoing election in his paper although, unfortunately, his newspaper did not comply with the "three times a month" publication requirement of Article 148. Some scholars say that these requirements are unconstitutional under Article 21.61 However, the Supreme Court upheld the requirements in 1979 , stating that the provision in question was not applied to "all reports and comments relating to elections, but ones which are likely to have effects of advantage or disadvantage on the poll of the particular candidate." 62 Despite the Supreme Court decision, there still remains considerable ambiguity in some respects. The Court seems to approve the punishment if there is only a possibility of harm. More basically, it is not certain that the "three times a month" requirement is needed in order to insure a fair election; nor is it certain how the requirement sufficiently justifies its restriction upon freedom of expression. The three requirements of Article 148 of the POEL on reports and comments seem to prevent people who do not have effective access to the media from expressing their own opinions about elections.

3. Restrictions on Election Campaigns and Democracy. Under the Constitutional principle of democratic government, the election is the most important opportunity for the people to participate directly in governmental affairs. The very foundation of democracy is that the people are allowed to express their own opinions sufficiently during the election process-that is, during free election campaigns. Of course, the election must be fair, but, at the same time, it must be free. During the election process, the people should be given enough information to judge and choose the direction of governmental affairs and should be offered sufficient opportunities to express themselves, to hear others, and to discuss public affairs. Without a sufficient guarantee of the people's rights to expression, information, and discussion, the constitutional principle of the people's sovereignty would become one in name only.

The extensive regulations under the POEL restrict the candidates' campaigns and, as a result, narrow the opportunities for the people to know

60. See, e.g., 23 Keishū 235; 18 Keishū 561 (Sup. Ct., Nov. 18, 1964); 9 Keishū 635 (Sup. Ct., Mar. 30, 1955); 4 Keishū 1799; 4 Keishū 819 (Sup. Ct., Apr. 6, 1950).

61. See, e.g., N. Ashibe, Enshū Kenpó 109 (1982); K. Sato, Chūshaku Nihonkoku Kenpō 490 (1984)

62. 952 Hanrei Jihō 17, 18 (Sup. Ct., Dec. 20, 1979). 
the issues of elections, the opinions of candidates, and the policies of political parties. The POEL also entirely excludes the people from participating in electoral campaigns. It exclusively regulates the relationship between candidates and the state. The law regards the sovereign people as a third party, as mere objects of a candidate's campaign. The restrictive measures of the POEL, such as the total ban on door-to-door canvassing and the extensive regulations on written materials, are excessively suppressive, harming particularly those people who are willing to express themselves actively or to participate in election campaigns for candidates on their own initiative.

Once the constitutional principles of democratic government and the people's sovereignty are recognized, then an election law should be enacted on the basis of those principles. The extensive restrictions under the current POEL must be thoroughly examined in light of the principles mentioned above.

\section{Restrictions on Political Campaigns under the Subversive Activities Prevention Law}

1. The Subversive Activities Prevention Law of 1952. The Subversive Activities Prevention Law ("SAPL") ${ }^{63}$ was enacted in 1952, soon after the termination of the Occupation and the effectuation of the San Francisco Peace Treaty. The law established regulatory and punitive measures against organizations that engaged in organized, violent subversive activities. The purpose of the SAPL was "the preservation of the public safety." 64 In the early 1950 s, as the Cold War between the West and the East escalated, Japan could not avoid becoming involved in the political and social tensions of the era. Thus, when the Peace Treaty came into effect, the SAPL was enacted as a substitute for the occupation laws. Its direct predecessor was a Cabinet Order of 1949 relating to the regulation of organizations. ${ }^{65}$ This order succeeded the Imperial Ordinance of February 1946, which was aimed at the activities of nationalistic and militaristic organizations. The Cabinet Order expanded its regulations to left wing organizations and required such organizations to report the names of their members.

As soon as it was proposed, the SAPL met with strong opposition because it reminded the people of their past experience under the Peace Preservation Law of 1925, which provided for capital punishment of those who organized or knowingly participated in an association whose purpose was to change the basic structure of the nation, the kokutai, or to repudiate the private property system. ${ }^{66}$ While the SAPL, like the Peace Preservation Law, was a thought control act, ${ }^{67}$ its regulatory methods and procedures were directly modeled

63. Subversive Activities Prevention Law, Law No. 240, 1952 [hereinafter SAPL]. For comprehensive studies on the law, see H. Otsuka, Tokubetsu Kejhō (1959); Bessatsu Hōritsu Jihō: Hakaikatsudō Bōshihō (1952) [hereinafter Bessatsu Hōritsu Jıhō].

64. SAPL,supra note 63 , art. 1.

65. Organizations Control Ordinance, Cabinet Order No. 64, 1949.

66. Watanabe, Seijiteki Hyogen no Jiyu Hori no Keiset, 33 Shakaikacaku Kenkyu 265, 290 (1981).

67. Id. at 295 . 
on the Smith Act of 1940 and the McCarran Act of 1951 in the United States. ${ }^{68}$ Although the SAPL did not clearly indicate an intent to control communism, its aim was, in fact, to counter communism. ${ }^{69}$ The opponents of the bill criticized it as being destructive of the freedoms of speech and association. In the end, the strong opposition during the Diet deliberation brought additional provisions to the law. For example, Article 2 provides that the law "must be applied within the narrowest possible limits necessary for the preservation of public safety, and it must not be interpreted broadly." Furthermore, Article 3 forbids abuses of authority and provides that "there shall not be any undue limitations on freedom of thought, religion, assembly, association and expression, academic freedom, the rights of workers to organize and to act collectively, and other freedoms and rights guaranteed by the Constitution of Japan."

There are two categories of regulations in the SAPL. The first category is aimed at the organization itself. An organization found engaging in violent subversive activities shall be banned from demonstrating, meeting, and publisning or distributing papers for a period not exceeding six months, and, where necessary, the Public Security Commission shall order dissolution of the organization. ${ }^{70}$ The second category focuses on individuals who engage in sucn activities. ${ }^{71}$ For example, Article 4 of the SAPL defines "violent subversive activities" as follows: (1) to engage in activities such as rebellion, subversion, and other particular crimes prohibited under the Criminal Code, ${ }^{72}$ or to incite, instigate, prepare, or conspire in such crimes with the intention to promote, support, or oppose any political doctrine or policy; or (2) to print, distribute, or post publicly any document or drawing insisting on the propriety or the necessity of the performance of rebellion, subversion, or assistance of subversion with the same intention. The SAPL also provides that it is a criminal act to prepare, conspire in, incite, or instigate the particular crimes prohibited under the Criminal Code, such as riot or obstruction of the execution of public duties, with the same intention. ${ }^{73}$

The regulation of the organization itself is through administrative prior restraint and not by criminal punishment. The procedures to pursue the restraint are initiated with a mere request by the Director of the Public Security Agency. The Director shall submit a written request stating the cause of the request to the Public Security Commission. The written request must be submitted with evidence or proof to establish the asserted fact and investigatory files produced in compliance with the SAPL. ${ }^{74}$ The SAPL authorizes the Commission to determine the appropriate administrative action, including the prohibition of organizational activities for a certain

68. Id. at $291-92$.

69. Bessatsu Hōritsu JıHō, supra note 63, at 13.

70. SAPL, supra note 63 , arts. $5,7$.

71. Id. art. 38.

72. Law No. 45,1907

73. SAPL, supra note 63 , arts. $39,40$.

74. Id. arts. $11,20$. 
period or the dissolution of the organization itself. ${ }^{75}$ The decision by the Commission may ultimately be appealed to the courts, but the procedures do not necessarily give the organization sufficient ability to defend itself.

The constitutionality of these SAPL provisions is doubtful. In fact, many scholars have questioned it, ${ }^{76}$ and, as a result, these provisions regulating an organization's activities have never been invoked. However, Article 27 grants extensive investigatory authority to public security investigators, stating that they "may make ... necessary investigations in relation to the regulation under this law." Up to the present, public security investigators have engaged in extensive investigations into communist organizations by various illegal means, including wiretapping, and clandestine photographing or videotaping. Recently, there have been revelations that the police placed wiretaps on an officer of the Japan Communist Party ("JCP") and that investigators took clandestine photographs and videotapes of the headquarters of the JCP. Because the means of enforcement adopted by investigators are illegal and intrusive to the right of privacy, another constitutional problem with the SAPL arises.

2. Developments under the Subversive Activities Prevention Law. As mentioned above, there has been no case involving the regulation of organizations under the SAPL, probably because these measures are too drastic and too likely to create a potential conflict with the constitutional guarantee of freedom of assembly and association. Thus, the only cases invoking the SAPL involved punishment of individuals' activities. Two types of cases have been brought, the first involving Article 38, paragraph 2, and the second involving Article 40. The former provision says that any person who prints, distributes, or publicly posts any document or drawing insisting on the propriety or the necessity of the performance of rebellion, with intention to perform such crime, shall be sentenced to imprisonment for not more than five years. The latter provision says that any person who prepares, conspires, incites, or instigates the obstruction of the execution of public duties or a riot, with the intention to promote, support, or oppose any political doctrine or policy shall be sentenced to up to three years' imprisonment.

There were four cases under Article 38. These cases took place in 1952 in Kushiro, Tsu, Kyoto, and Gifu. In the Kushiro case, ${ }^{77}$ two workers were indicted for distributing an election campaign document that read, "Only fighting with armament can lead us to a great victory." In 1954, the Kushiro District Court acquitted the defendants, stating that the document in question was only propaganda material in the election, and that the document's content, neither in whole nor in part, insisted upon the propriety or the necessity of rebellion. According to the Kushiro District Court, application of

75. Id. art. 22.

76. M. Ito, supra note 27, at 290, 293; N. Kobayashi, Shinpan Kenpō Kōgi 446-47 (1980); Watanabe, supra note 66 , at 304-06.

77. 36 Hanrei Jihō 3 (Kushiro Dist. Ct., Sept. 15, 1954). 
this provision of the SAPL should be limited only to instances in which the speech caused a clear and imminent danger that brought great harm to public safety. In 1956 the Sapporo High Court affirmed. ${ }^{78}$ In these decisions, however, the provision itself was not declared to be unconstitutional on its face.

In three other cases, ${ }^{79}$ affiliates of the JCP were indicted for distributing documents that read, "We have to start preparing for armament." In these cases, the courts found that the documents insisted upon the propriety or the necessity of rebellion. At the same time, the courts did not find that the defendants had any intention to perform rebellion. Consequently, they were acquitted. According to the courts, in order to find an intention of rebellion, there must be knowledge of the content of the document, an intention to perform rebellion, and a probability of actual rebellion. "When there is no clear and imminent danger which causes the harm, to restrict and punish the speech on an estimated future harm is contrary to the basic principle of democracy." 80 But once again, Article 38, paragraph 2, was not invalidated on its face. The references to "clear and imminent danger" in those decisions were remarkable, but the concept was used as one factor for factfinding, not as a standard for constitutional review. These cases were affirmed by the high courts of Nagoya and Osaka and by the Supreme Court. ${ }^{81}$

There are two cases under Article 40 of the SAPL. In the first, three leaders of the Middle Core Faction, a leftist political group, were indicted for a violation of Article 40. They made speeches in front of many students and workers at four political meetings held between April 17 and 24, 1969, and they called upon the students and workers to "occupy the Capitol and seize the Prime Minister's residence." The meetings were aimed at Okinawa Day on April 28, and were to demonstrate opposition to government policy on Okinawa. The leaders were accused of inciting a riot and obstruction of execution of public duties. In 1985, the Tokyo District Court declared them guilty, stating that the SAPL was enacted to proscribe subversive activities against parliamentary democracy; that the SAPL was aimed at the acts of incitement or instigation, not at thought itself; and that, therefore, the SAPL did not violate Article 19 (freedom of thought) or Article 21 of the Constitution. ${ }^{82}$ The court also said that Article 40 of the SAPL did not require an actual danger, but an abstract one, and that there was an abstract

78. 74 Hanrei Jihō 21 (Sapporo H. Ct., Mar. 30, 1956).

79. 183 Hanrei Jihō 5 (Gifu Dist. Ct., Jan. 27, 1959); 112 Hanrei Jihō 1 (Kyoto Dist. Ct., Dec. 27, 1956); 48 Hanrei Jihō 3 (Tsu Dist. Ct., Feb. 28, 1955).

80. 48 Hanrei Jihō, at 15.

81. 496 Hanrei Jihō 68 (Sup. Ct., July 20, 1967), aff'g 4 Kakeishū 1001 (Nagoya H. Ct., Dec. 24, 1962); 496 Hanrei Jihò 76 (Sup. Ct., Sept. 22, 1967), aff'g 456 Hanrei Jihō 16 (Osaka H. Ct., Apr. 21, 1966); 396 Hanrei Jihõ 19 (Sup. Ct., Dec. 21, 1964), aff'g 396 Hanrei Jihō 24 (Nagoya H. Ct., Jan. 14, 1964).

82. 1146 Hanrei Jihō 35 (Tokyo Dist. Ct., Mar. 4, 1985). 
danger generally in this case ${ }^{83}$ The Tokyo High Court affirmed the conviction and upheld the constitutionality of the provision. ${ }^{84}$

The second case was much like the first. A leader of the Middle Core Faction, who had given a radical speech at a political meeting, was indicted for violating Article 40 of the SAPL. The Tokyo District Court declared him guilty. ${ }^{85}$ According to the court, the provision did not violate Article 21 of the Constitution because it did not punish the actual content of the expression; rather, it punished conduct considered to be socially dangerous. The Tokyo High Court affirmed this decision in $1988 .{ }^{86}$ The high court said that the action of incitement was dangerous by itself; therefore, punishment of such action did not violate Article 21 of the Constitution.

In these two cases, there were lag periods between the speeches and the asserted riots-the longest being eleven days. However, the police had done nothing to avoid the riots during these lag periods. The courts seem to have disregarded too easily the degree of imminence of danger. ${ }^{87}$ Nonetheless, on September 28, 1990, the second Petty Bench of the Supreme Court affirmed these two high court decisions, stating that the provision in question, Article 40 of the SAPL, did not violate Articles 19 and 21 of the Constitution because it did not aim at thought or speech itself, but at an act of incitement. ${ }^{88}$

In addition to the cases mentioned above, there were two other SAPL cases. In the Sammu case, twelve members of an anticommunist group were accused of planning a coup d'etat, acquiring weapons and bullets, and undergoing training to use the weapons. They were indicted for preparation for murder and riot in violation of Articles 39 and 40 of the SAPL. The Tokyo District Court declared them guilty in $1964,,^{89}$ and the Tokyo High Court affirmed that decision in 1967.90 In 1970, the Supreme Court dismissed the appeal, stating that Articles 39 and 40 did not violate the guarantee of due process under Article 31 of the Constitution. ${ }^{91}$ In the Sekigun case, members of an extreme leftist group who engaged in training for an attack on the Prime Minister's residence were convicted under Articles 39 and 40 of the SAPL. 92

3. An Appraisal of the Subversive Activities Prevention Law. One commentator remarked that "there was no truth at all that freedom of speech, expression, assembly, and thought was deprived or restricted" by enactment of the SAPL; "rather, violent subversive activities disappeared by the enactment of the law,

83. Id. at 41.

84. 1232 Hanrei Jihō 43 (Tokyo H. Ct., Mar. 16, 1987).

85. 17 Keisai Geppo 957 (Tokyo Dist. Ct., Oct. 16, 1985)

86. 1308 Hanrei Jihō 157 (Tokyo H. Ct., Oct. 12, 1988).

87. Y. Okudaira, Naze Hyōgen no Jiyũ ka 70 n.63 (1988); Ebashi, Seijiteki Köi to Hyögen no Jiyū no Taiyō, 64 НАвōHō Kenkyū 18, 23-24 (1989); Okudaira, Zoku Genron Hanzai Kō, HōGaku Seminar, Jan. 1985 , at $8,11$.

88. Unpublished Sup. Ct. decision, Sept. 28, 1990.

89. 6 Kakeishū 694 (Tokyo Dist. Ct., May 30, 1964).

90. 492 Hanrei Jihō 20 (Tokyo H. Ct., June 5, 1967).

91. 24 Keishū 412 (Sup. Ct., July 2, 1970).

92. 1088 Hanrei Jihō 3 (Tokyo H. Ct., July 27, 1983); 989 Hanrei Jihō 8 (Tokyo Dist. Ct., Jan 30, $1980)$. 
and the law has adequately achieved its purpose 'to contribute to maintenance of public security." "93 However, this kind of appraisal does not seem to be justifiable. The SAPL is a typical sedition law aimed at controlling assembly, association, speech, press, and thought.

There have been many questions posed about the constitutionality of the SAPL since its enactment in 1952. Consequently, as noted above, the provisions for regulating organizations have never been invoked. The courts have not approved the constitutionality of provisions punishing the distribution of documents advocating the propriety and necessity of rebellion. Instead, they have found that most cases lacked clear and imminent danger. However, punishment for speeches at political meetings was upheld by the courts because of general dangers that caused harm to public security. In those cases, however, the courts did not require the existence of actual danger in order to punish incitement. Therefore, it is doubtful whether punishing a person for delivering a speech when there is no clear and imminent danger is compatible with the constitutional guarantee of freedom of expression. Some scholars believe that the punishment of speech should be limited to cases where there is a clear and imminent probability of danger that results in actual harm. ${ }^{94}$

\section{Restrictions on Demonstrations under the Public Safety Ordinances}

1. Outline of the Restrictions of the Public Safety Ordinances. Many restrictions on political campaigns and activities in public forums arise from various laws and local public entities' ordinances, such as restrictions on demonstrations under public safety ordinances, restrictions on sidewalk speeches under the Road Traffic Law, ${ }^{95}$ restrictions on handbill activities under the Misdemeanor Law $^{96}$ or the outdoor advertisement laws, ${ }^{97}$ and restrictions on the use of loudspeakers in certain areas, including around the Diet, under the Quiet Preservation Law. ${ }^{98}$ It has been asserted that these restrictions are necessary to preserve regional peace, traffic order, city scenery, property rights, and low noise levels. ${ }^{99}$ However, whether all of these restrictions can be supported by

93. Fujinaga, Hakaikatsudō Böshihō, in 8 Hanreı Keınō Kenkyū 319 (H. Nishihara, K. Miyazawa, J. Abe, H. Itakura, M. Otahi \& K. Shibahara eds. 1981).

94. See, e.g., Shimizu, Hakaikatsudo Boshiho no Sendozai no Gokensei, in 1985 Jurist Jyūyō HaNreI KAISETSU 20, 21 (1986).

95. Road Traffic Law, Law No. 105, 1960 (restrictions on the use of streets).

96. Misdemeanor Law, Law No. 39, 1948 (restrictions on handbill activities).

97. Outdoor Advertisement Law, Law No. 189, 1949 (restrictions on outdoor advertisement). Most local public entities have their own outdoor advertisement ordinances.

98. Quiet Preservation Law, Law No. 90, 1988 (regulation of the use of loudspeakers in certain areas).

99. See, e.g., 41 Keishū 15 (Sup. Ct., Mar. 3, 1987) (regulation of posters under the Oita outdoor advertisement ordinance); 36 Keishũ 908 (Sup. Ct., Nov. 16, 1982) (permission by a chief of police required by Road Traffic Law to use street for demonstration); 24 Keishū 280 (Sup. Ct., June 17, 1970) (restriction on handbill activities under the Misdemeanor Law); 22 Keishū 1549 (Sup. Ct., Dec. 18, 1968) (restriction on outdoor advertisement under the Outdoor Advertisement Law and the Osaka outdoor advertisement ordinance); 14 Keishū 253 (Sup. Ct., Mar. 3, 1960) (permission for sidewalk speech under the Road Traffic Law). For regulation of the use of loudspeakers in certain areas, see Usaki, Genron to Souon no aida, 61 Hōritsu Jıō, No. 8, 56 (1989). 
the Constitution is doubtful. The restrictions on demonstrations under the public safety ordinances have been the most controversial.

The public safety ordinances are the ordinances of local public entities that are designed to preserve regional peace through restrictions on demonstrations and other collective activities. Before the war, the Peace Police Law of 1900 authorized the police to restrict or prohibit outdoor meetings, demonstrations, sidewalk speeches, and other collective activities. However, the public safety ordinances were substituted for the Peace Police Law after its abolition in 1945. At present, Tokyo, twenty-four prefectures, and thirty-five cities have these ordinances. ${ }^{100}$ The enactment of public safety ordinances began with the Osaka city ordinance of 1948 , and reached its peak in 1949 when Tokyo, twenty prefectures, and nineteen cities enacted their ordinances. ${ }^{101}$ During the same period, small towns and villages also enacted ordinances, but all of these were repealed in 1954 when the Police Law was amended. ${ }^{102}$ The GHQ provided strong influence and guidance in enacting the ordinances, and its intent was to prepare for the preservation of peace in Japan in advance of the Korean War. ${ }^{103}$ However, the Constitution of Japan already provided in Article 21 that "[f]reedom of assembly and association as well as speech, press and all other forms of expression are guaranteed. No censorship shall be maintained ...." Thus, the constitutionality of the public safety ordinances has been questioned since their enactment.

The Tokyo Metropolitan Ordinance of 1950 provides an example of the structure of restrictions under the public safety ordinances. ${ }^{104}$ Under Article 1 of this ordinance, any person who intends either to hold a meeting or to walk in a parade, on a street or in any other public forum, or who intends to demonstrate regardless of place, shall ask for the permission of the Tokyo Public Safety Commission. Article 2 requires the individual, or a representative of the organization, to submit an application for permission seventy-two hours before the event. Under Article 3, the Commission may refuse permission or may impose additional conditions on the permit when it clearly finds that the meeting, parade, or demonstration is likely to cause direct danger to the preservation of public safety. Under Article 5, if the meeting, parade or demonstration takes place without prior permission or in violation of the additional conditions, the person responsible for the meeting, parade, or demonstration shall be sentenced to imprisonment not exceeding one year or fined in an amount not exceeding fifty thousand yen.

Other ordinances have similar restrictions. Five ordinances substitute notification systems for the permission system of the Tokyo ordinance, and two require notification for meetings and permission for parades or demonstrations. Twenty-four do not regulate the holding of meetings. Forty-

100. O. Ozaki, Kōanjōōei Seitei Hishi 185 (1978). See also Hōritsu Jihō Rinjizōkan, KōanJYōreI 135-37 (1967).

101. O. OzaKI, supra note 100 , at 188.

102. Id. at 187 .

103. Id. at 159-84.

104. Tokyo Metropolitan Ordinance No. 44, July 3, 1950. 
eight ordinances limit the time for notification or for permit applications to seventy-two hours before the meeting, parade, or demonstration, while eleven set a forty-eight hour time limit and one has a twenty-four hour time limit. ${ }^{105}$ Most ordinances, including the Tokyo ordinance, have some provision to inhibit administrative abuse. However, in practice, the ordinance restrains or limits political campaigning and other activities of the people in the same manner as a so-called "functional" 106 or "curved"107 sedition law.

Where there is no public safety ordinance, Article 77 of the Road Traffic Law requires permission from the Chief of Police to hold a parade or demonstration on the road. The chief may refuse permission or may impose "necessary conditions" when the parade or demonstration is likely to obstruct traffic. Thus, the Road Traffic Law quite possibly provides a functional substitute for public safety ordinances. ${ }^{108}$

2. Developments under the Public Safety Ordinances. The first important dispute on the constitutionality of the public safety ordinances happened in Niigata in 1949. In this case, several hundred Koreans demonstrated at the police station without prior permission, demanding the release of fellow Koreans who had been arrested on charges of illicit brewing. The leaders of the demonstration were indicted for violating the Niigata public safety ordinance and convicted by the lower court. In 1954, the Supreme Court upheld the convictions and dismissed the appellants' contention that the ordinance established an unconstitutional prior restraint on freedom of assembly. ${ }^{109}$ However, the Court set three constitutional requirements for upholding the constitutionality of an ordinance: (1) placing prior restraints on demonstrations through a general permission system is impermissible; (2) a notification system based upon reasonable and clear criteria regarding the specific place and means of demonstrations is not unconstitutional; and (3) when clear and imminent danger to public safety is expected, failure to permit the demonstration does not violate the Constitution. ${ }^{110}$

As a result, in 1959, when two student leaders of a demonstration against an amendment to the Police Duties Execution Law were accused of violating the Tokyo ordinance, the Tokyo District Court acquitted them, relying upon the Supreme Court decision in the Nigata ordinance case." stated that the ordinance did not clearly define the criteria for obtaining

105. O. OzaKı, supra note 100, at 186; Hōritsu JiHō RinjızōKan, supra note 100, at 135-57.

106. М. КаNEко, Chianrippō-selsu kara mila Köanjyörei Göken Hanketsu, 208 JuRist 57, 61 -62 (1960). Professor Kaneko points out that public safety ordinances necessarily perform the function of indirectly and subordinately suppressing antigovernment ideologies, and he therefore called the ordinance "the modern type of sedition law." Id. at 61 .

107. R. ARikURa, supra note 28, at 301-23.

108. See 36 Keishū 908 (Sup. Ct., Nov. 16, 1982).

109. 8 Keishũ 1866 (Sup. Ct., Nov. 24, 1954).

110. Id. at 1872-73.

111. 14 Keishū 1281 (Tokyo Dist. Ct., Aug. 8, 1959). 
permission to demonstrate. However, the Supreme Court reversed the decision of the Tokyo District Court in 1960.112

The Supreme Court deemed the demonstrators to be "potential rioters." Furthermore, the Court stated that unlike mere speech or use of the press, expression through collective activities potentially involved support from physical force, and that this potential force often created excitement that was likely to turn a demonstration into a riot in a moment. ${ }^{113}$ Although there was a slight reference to the Constitution, the Court made no fair evaluation of collective activities, such as demonstrations, in light of the constitutional guarantee of freedom of expression. Despite the prohibition of censorship by Article 21, paragraph 2, of the Constitution, the Court stated that as far as freedom of expression through demonstration was concerned, it was necessary, after considering regional and other circumstances, to take minimum measures in advance to preserve law and order through a public safety ordinance by preparing for unexpected incidents. ${ }^{14}$ In the end, the Court concluded:

In short, collective activities regulated by the ordinance, especially demonstrations, are far outside the scope of freedom of pure expression, which ought to be performed quietly and orderly, and collective activities contain physical force which is likely to turn into violence. Thus, it may not be said that a certain degree of regulation of these activities is unnecessary. The State and society must respect freedom of expression for the most part, but it is really unavoidable to expect in advance activities which destroy peace and order under the pretext of the exercise of freedom of expression, or which are likely to do so, and to take appropriate measures in preparing for any unexpected incidents. Of course, it will not be said that there is absolutely no risk that the ordinance may infringe upon the freedom of expression guaranteed by Article 21 of the Constitution. It is a matter of course to superintend the Public Safety Commission, which is responsible for execution of the ordinance so as not to abuse its authority under the pretext of preservation of public safety, and so as not to suppress peaceful and orderly collective activities. However, even though the ordinance may be abused, it is not appropriate to hold that the ordinance is unconstitutional. ${ }^{115}$

Two justices wrote dissenting opinions in the case, ${ }^{16}$ and many scholars criticized the majority opinion of the Court. ${ }^{117}$ In addition, several lower courts declared public safety ordinances to be unconstitutional, relying on the Supreme Court decision in the Niigata case. For example, in 1967, the Kyoto District Court struck down the Kyoto city ordinance as unconstitutional on its face. ${ }^{118}$ In the same year, the Tokyo District Court declared the Tokyo ordinance to be unconstitutional as applied in one case, ${ }^{119}$ and it acquitted defendants by interpreting the ordinance strictly in another case. ${ }^{120}$ In 1975 , the Supreme Court once again had an opportunity to review the

112. 14 Keishū 1243 (Sup. Ct., July 20, 1960).

113. Id. at 1248 .

114. Id.

115. Id. at $1250-51$.

116. Id. at 1251 (Fujita, J. dissenting); id. at 1256 (Tarumi, J., dissenting).

117. See, e.g., N. Kobayashi, supra note 76, at 455 n.54. For articles by professors M. Itoh, I. Sato,

K. Shoji, T. Kikkawa, M. Kaneko, M. Ikeda, and others, see 208 Jurist, Aug. 15, 1960.

118. 480 Hanrei Jihō 3 (Kyoto Dist. Ct., Feb. 23, 1967).

119. 9 Kakeishū 638 (Tokyo Dist. Ct., May 5, 1967).

120. 9 Kakeishū 699 (Tokyo Dist. Ct., May 30, 1967). 
constitutionality of a public safety ordinance in the Tokushima case. ${ }^{121}$ In this case, a leader of an antiwar group was indicted for violation of the city ordinance that required demonstrators to "preserve traffic order." One of the issues in this case was whether the ordinance violated the constitutional guarantee of due process of law under Article 31. Although the Supreme Court admitted the ordinance lacked "propriety as legislation," it emphasized that an ordinary person could read the meaning of the provision as applying only to acts that intentionally obstructed traffic order. The Court declared that the provision of the ordinance did not lack clarity and therefore was not unconstitutional. ${ }^{122}$

Shortly after the Tokushima case, the Supreme Court upheld a conviction in another Tokyo ordinance case, but only on the ground that, while the demonstration took place peacefully, it took place without official permission of the Public Safety Commission. ${ }^{123}$ The decision meant that collective activities without official permission were illegal in both form and substance, thus restraining the trend in the lower courts to interpret the ordinances strictly. In addition, in 1982, the Court upheld a conviction for a demonstration without permission under the Road Traffic Law. ${ }^{124}$

3. The Public Safety Ordinances and Freedom of Political Expression. Collective activities such as parades and demonstrations are included in "all other forms of expression" in Article 21 of the Constitution. Moreover, collective activities play an extremely important role in a democratic society. As the Kyoto District Court decision said, ${ }^{125}$ collective activities are the primary means of expression for people who, due to economic reasons, lack access to the comparatively more effective mass media, such as publication and broadcasting. Collective activities supplement the process of representative government, and they should therefore be evaluated as forms of expression.

However, expression through collective activities is accompanied by physical limitations. An activity involving a group larger than the forum is capable of holding is impossible, and several groups cannot use the same forum at the same time. Thus, some restrictions on collective activities are needed in order to maintain traffic order, to secure public properties, and to protect participants. Therefore, regulation of activities under clear criteria for their time, place, and manner should be acceptable. Needless to say, such criteria should be content-neutral, not content-based. Any restriction on collective activities which is content-based must be viewed as a form of censorship prohibited by the Constitution. Permissible criteria are those that

121. 29 Keishū 489 (Sup. Ct., Sept. 10, 1975).

122. Id. at 503-06.

123. 29 Keishũ 777 (Sup. Ct., Oct. 24, 1975). In the same year the Court upheld convictions under public safety ordinances in three other cases. See 29 Keishū 860 (Sup. Ct., Oct. 24, 1975) (Osaka city ordinance case); 29 Keishū 657 (Sup. Ct., Sept. 26, 1975) (Kanagawa ordinance case); 29 Keishū 610 (Sup. Ct., Sept. 25, 1975) (Aichi ordinance case).

124. 36 Keishũ 908 (Sup. Ct., Nov. 16, 1982).

125. 480 Hanrei Jihō 7 (Kyoto Dist. Ct., Feb. 23, 1967). 
govern only time, place, and manner, regardless of content, and that do not give any discretion, or any room for abuse, to safety commissions and the police who execute the ordinances. Any conditions that the safety commissions may place on collective activities must also be content-neutral, controlling only the time, place, or manner of such activities. However, if a commission demands an overall change of time or place before allowing such activities, it may, in effect, deny permission to go forth with the activities as originally planned. At present, the restrictions on demonstrations under the public safety ordinances are far beyond permissible limits and far removed from the constitutional guarantee of freedom of expression.

\section{III}

\section{Conclusion}

It is obvious that the Constitution of Japan adopts the principle of democratic government and guarantees various rights and freedoms underlying it. However, I have many questions about whether democracy has actually been realized under this Constitution because of the various and extensive restrictions on political campaigns and other activities essential to democracy. Many of these restrictions are beyond the limit necessary to ensure and preserve democracy.

With regard to the outright prohibition of political activities by public employees to maintain administrative neutrality under both the NPEL and the LPEL, there is a suspicion that those prohibitions impermissibly restrain the constitutionally protected political and civil rights of public employees. Furthermore, the POEL's various restrictions on election campaigns seem to prevent the people's participation in governmental affairs, in direct contrast to the law's goal of ensuring fair elections. Moreover, the SAPL imposes extensive and unreasonable restrictions on the freedoms of assembly, association, speech, and press. It is safe to say that the law, in substance, is a typical sedition law aimed at controlling anti-government ideologies and activities. Finally, there have been many restrictions on political campaigns and activities in public forums under the public safety ordinances and other laws. These restrictions are formally intended to secure legitimate interests such as property rights, regional peace, traffic order, city scenery, and area quiet, but, in effect, they function as laws to control anti-government expression. Therefore, they may be characterized as "functional" or "curved" sedition laws.

Three factors can be identified as causes for the inadequacy of the present situation, which is contrary to the constitutional guarantee of freedom of political activities. First, many of these restrictions originated from the policies of the GHQ during the military occupation after World War II. The restrictions on political and civil rights under the Occupation should have been exceptions to the Constitution, and therefore, repealed at the time of the Occupation's termination. It was extremely unfortunate for the Constitution and for democracy in Japan that the enactment of the Constitution and the 
formation of the basic framework of the government after World War II took place under a military occupation. Second, since both democracy and democratic government were completely new to the Japanese people, they were politically immature and unfamiliar with democratic institutions. As a result, this brought about the long-lived conservative regime in the postwar period, and both the government and the people tended to lose sensitivity and tolerance for minorities. Consequently, various restrictions on political freedom have remained. Third, and most important, it should be pointed out that the concept that political freedom occupies a preferred position among protected rights has not matured sufficiently in constitutional theory. Except for a few legal scholars, the courts, the lawyers, and the people were all unfamiliar with the system of judicial review which was adopted for the first time by the 1947 Constitution. Therefore, they have been willing to accept many restrictions on political freedom from ambiguous and equivocal "public welfare" concepts, without any close examination of what these concepts actually entail. As a result, they seem to have neglected to form a sufficient framework in constitutional theory to deal with political freedom.

Throughout the history of the 1947 Constitution, Japan has accomplished a rapid economic development but has accumulated many political problems incompatible with the principles of its Constitution. For the solutions to these problems, we must look toward the fifth decade of the Constitution. 